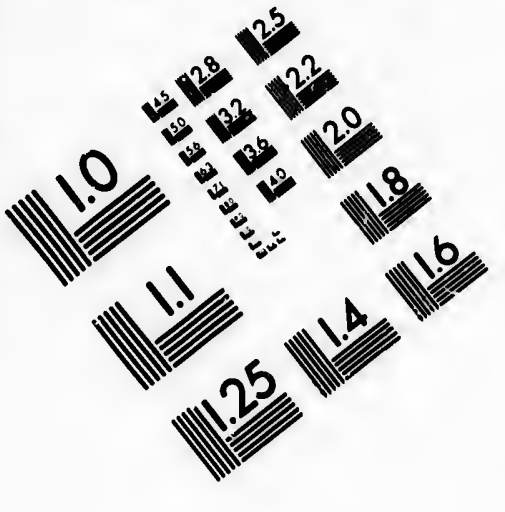

IMAGE EVALUATION

TEST TARGET (MT-3)
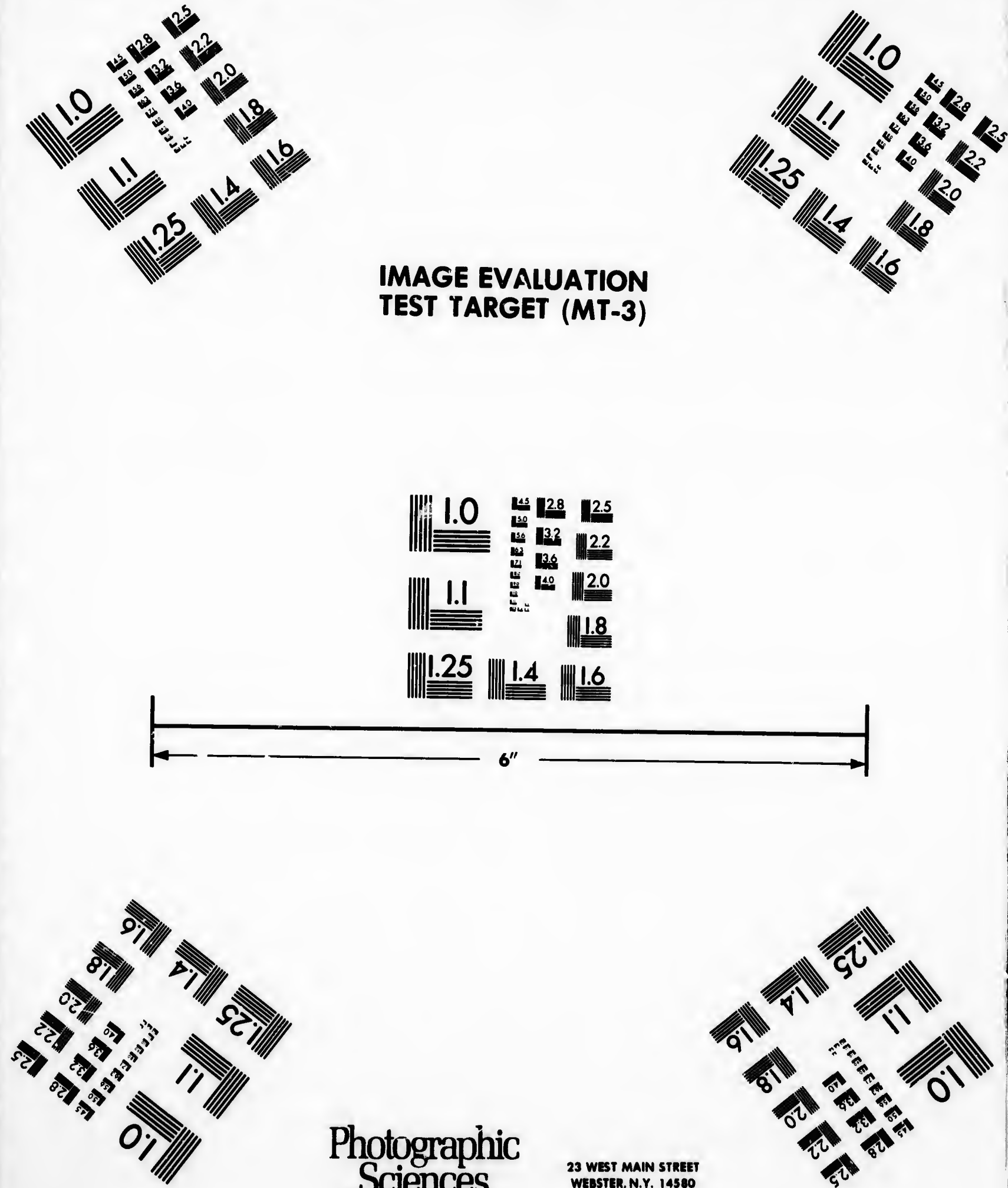

Photographic Sciences

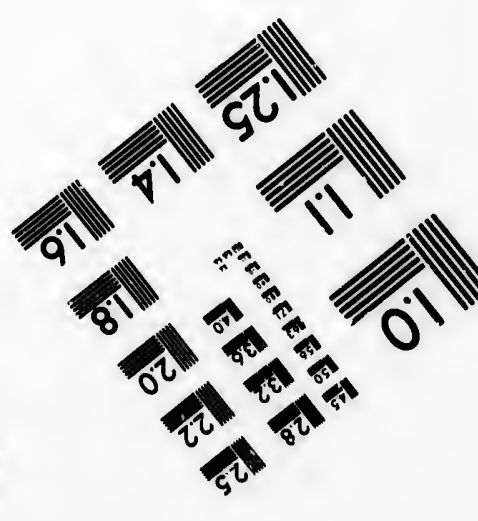
Corporation 


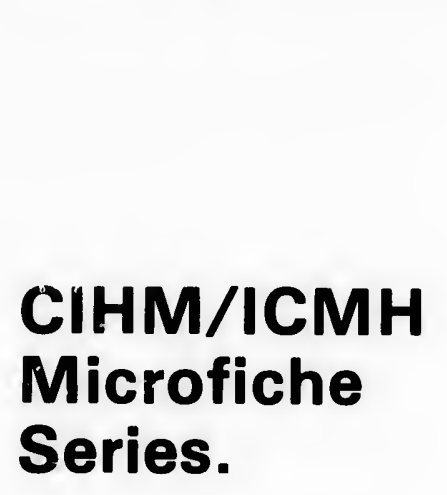

\section{CIHM/ICMH Collection de microfiches.}

Canadian Institute for Historical Microreproductions / Institut canadien de microreproductions historiques
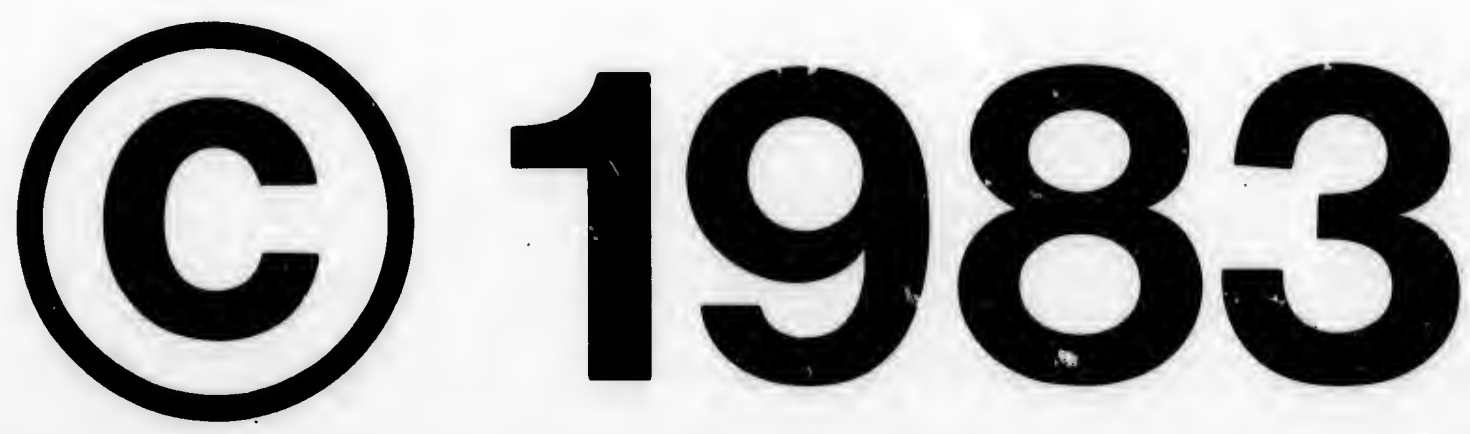
The Institute has attempted to obtain the best original copy available for filming. Features of this copy which may be bibliographically unique, which may aitar any of the images in the reproduction, or which may significantly change the usual method of filming, are checked below.

\section{Coloured covers/}

Couverture de couleur

\section{Covers dạmaged/}

Couverture endommagée

Covers restored and/or laminated/

Couverture restaurée et/ou pelliculée

Cover title missing/

Le titre de couverture manque

\section{Coloured maps/}

Cartes géographiques en couleur

Coloured ink (i.e. other than blue or black)/

Encre de couleur (i.e. autre que bleue ou noire)

Colourad plates and/or illustrations/

Planches et/ou illustrations en couleur

Bound with othar material/

Ralié avec d'autres documents

Tight binding may cauee shadows or distortion along interior margin/

La re liure serrée peut causer de l'ombre ou de la distortion le long de la marge intérieure

Blank laaves added during restoration may appear within the text. Whenever possible, these have bean omitted from filming/

II se peut que certaines pages blanches ajoutées lors d'une restauration apparaissent dans le texta, mais, lorsque cela était possible, ces pages n'ont pas eté filmóes.

\section{Addizional comments:/}

Commentaires supplémentaires:
L'Institut a microfilme te meilleur exemplaire qu'il lui a été possible de se procurer. Les détails de cet exemplaire qui sont peut-être uniques du point de vue bibliographique, qui peuvent modifier une image reproduite, ou qui peuvent exiger une modification dans la mbthode normale de filmage sont indiqués ci-dessous.

Coloured pages/

Pages de couleur

Pages damaged/

Pages endommagées

Pages restored and/or laminated/

Pages restaurées et/ou pelliculées

Pages discoloured, stained or foxed/

Pages décolorées, tachetées ou piquées

Pages detached/

Pages détachées

Showthrough/

Transparence

Quality of print varies/

Qualité inégale de l'impression

Includes supplementary material/

Comprend du matériel supplémentaire

Only adition available/

Seule edition disponible

Pages wholly or partially obscured by errata slips, tissues, etc.. have been refilmed to ensure the best possible image/

Les pages totalement ou partiellement obscurcies par un feuillet d'errata, une pelure. etc., ont été filmées à nouveau de façon a obtenir la meilleure image possible.

This item is filmed at the reduction ratio checked below/ Ce document est filmb au taux de róduction indiqué ci-dessous.

$10 x$

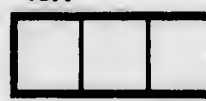

$14 x$

$18 x$

$22 x$

$26 x$

$30 x$

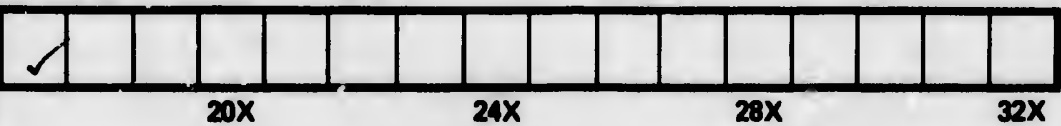


The copy filmed hare has been reproduced thenks to the genorosity of:

\author{
Bishop's University \\ Lennoxville
}

The images appearing here are the beat quality possible considering the condition and legibility of the original copy and in keeping with the filming contract epeclfications.

Original copies in printed paper covers are filimed beginning with the front cover and ending on the last pege with a printed or illustrated impression, or the beck cover when eppropriate. All other original coples are filmed boginning on the first page with a pritited or llluatrated impression, and ending on the last page with a printed or illustrated impreasion.

The leat recorded freme on eech microfiche ahall contain the symbol $\longrightarrow$ Imeaning "CONTINUED"), or the symboi $\nabla$ (meening "END"). whichover applies.

Maps, piates, charts, etc., may be filmed at different reduction retios. Those too large to be entirely inciuded in one exposure are filimed beginning in the upper loft hand cornor, left to right and top to bottom, as many frames as required. The following diagrams iliuatrate the mothod:
L'exemplaire fillme fut reproduit grâce à la gonorositó de:

\section{Bishop's University \\ Lennoxville}

Lus images suivantes ont bt' reproduites avec le plus grand soin, compte tenu de la condition et de la nettet's de l'exemplair i filmb, et en conformite avec les conditions du contrat de filimage.

Les exemplaires originaux dont la couverture en papier eat imprimbe sont flimbs en commençant par lo promier plet ot en terminant soit par la dernibre page qui comporte une empreinte d'impression ou d'illustration, soit par le second plat, seion le cas. Tous les autres exemplaires originsux sont filimbs an commançant par la premidre page qui comporte une empreinte d'impression ou d'illustration et en terminent par la dernière page qui comporte une telle empreinte.

Un des symboles suivants apparaitra sur la dernidre image de chaque microfiche, selon le cas: le symbole $\longrightarrow$ signifie "A SUIV'RE", le symbole $\nabla$ signifie "FIN".

Les cartes, planches, tableaux, etc.. peuvent etro filmes des taux de réduction diffórents. Lorsque le document est trop grand nour etre reproduit on un seul clichs, il est film.d a partir de l'angle supbrieur gauche, de gauche a droite. ot de haut on bas, en prenant le nombre d'images nócessaire. Les diagrammez suivants lliustrent la mothooe.
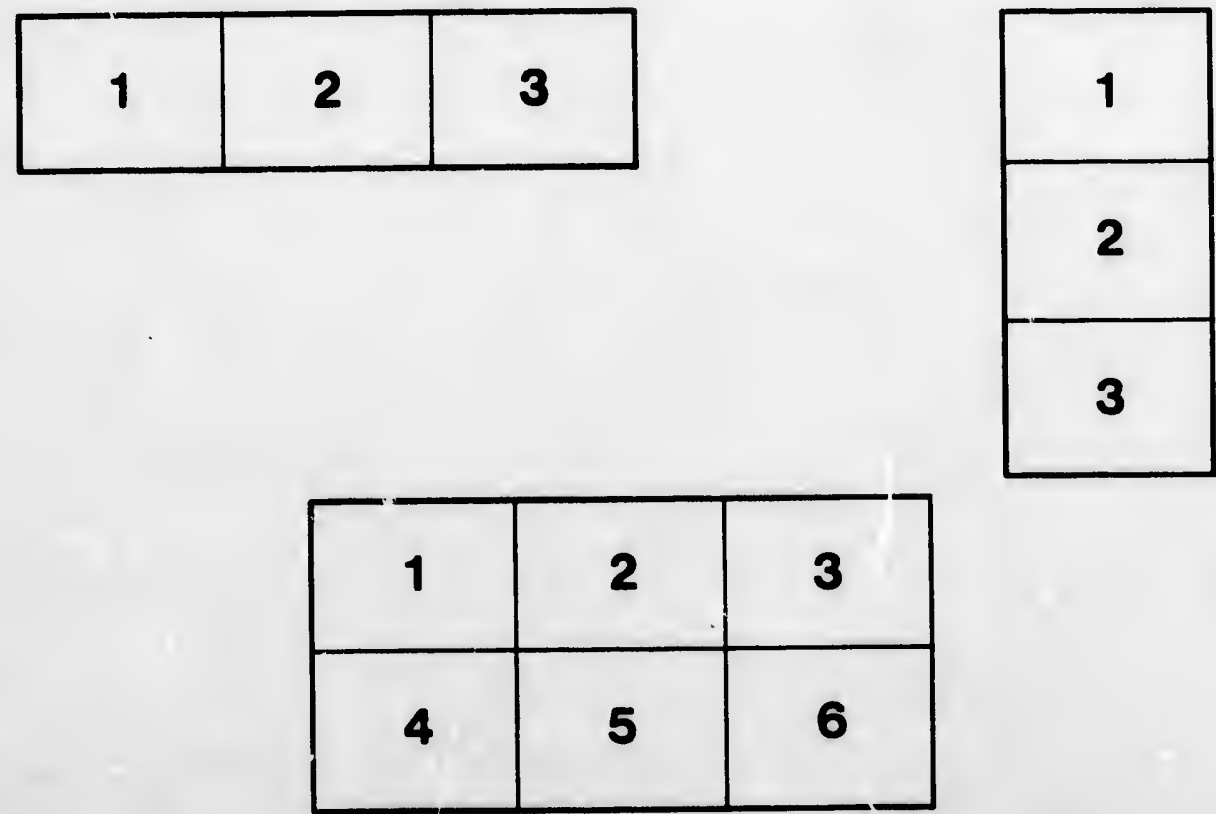
$\Rightarrow$ PRIZE LIST

- OP THE -

COUNTY OF BROME

A gricultural Society FrOIR 1890.

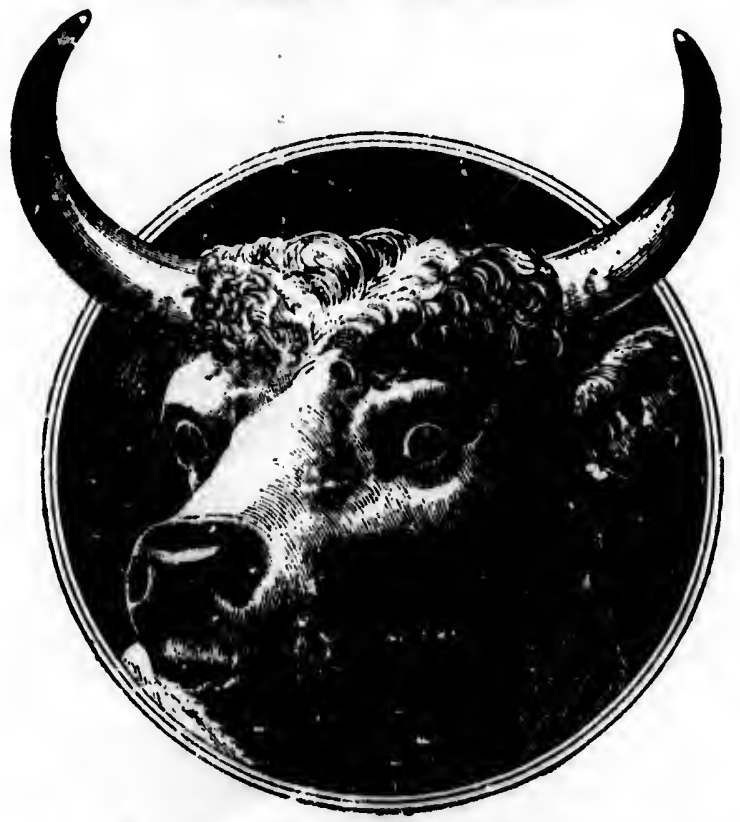

\title{
The Annual Fall Exhibition
}

\author{
-W WILL yU HELD AT - \\ BROME CORNER, P. Q.,
}

Tuesday \& Wednesday; Sept. 12 \& 13, 1899.

\author{
H. $\therefore$ SMITH, PRINTER, KNOWLTON, QUE,
}




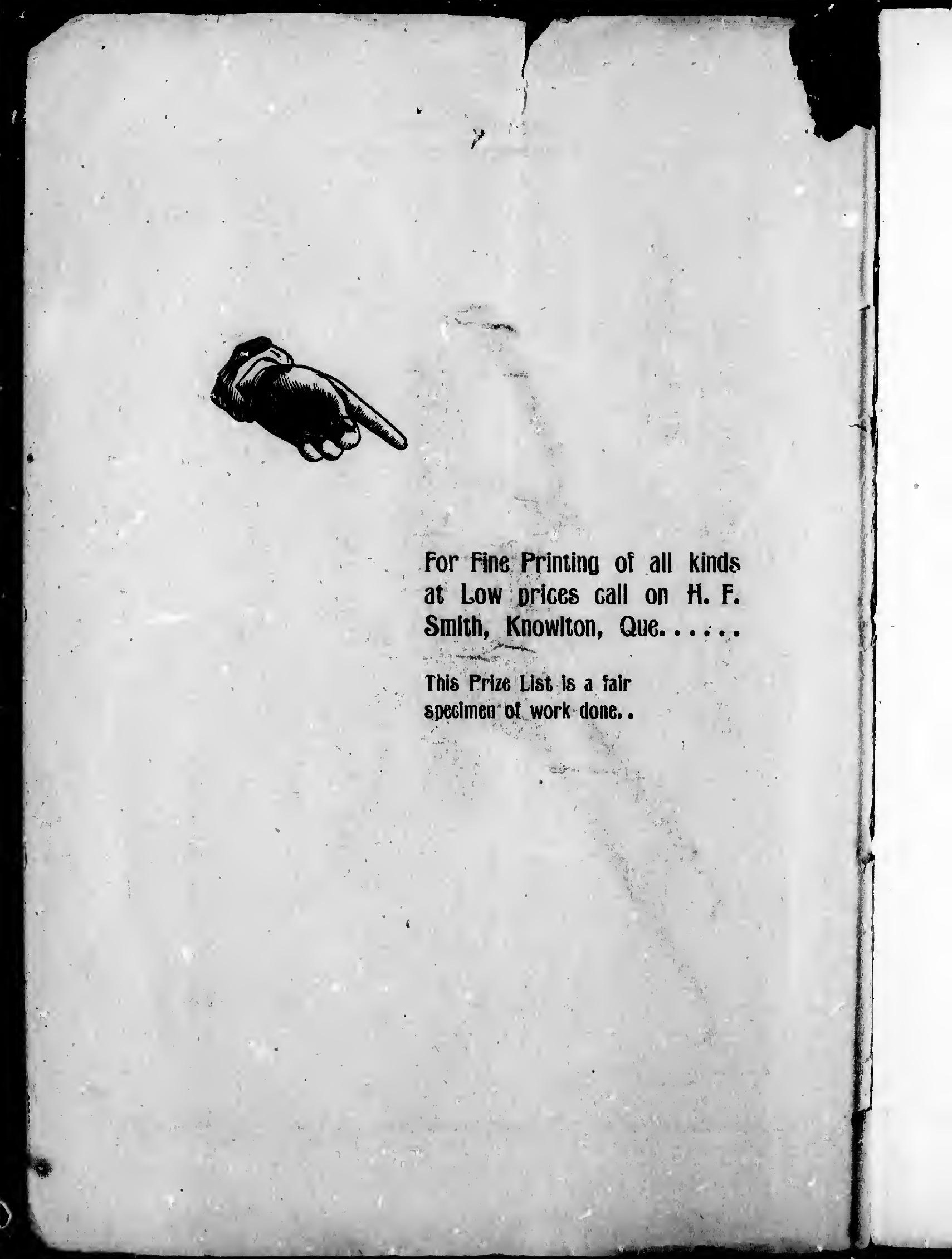


Adverpisement.

i.

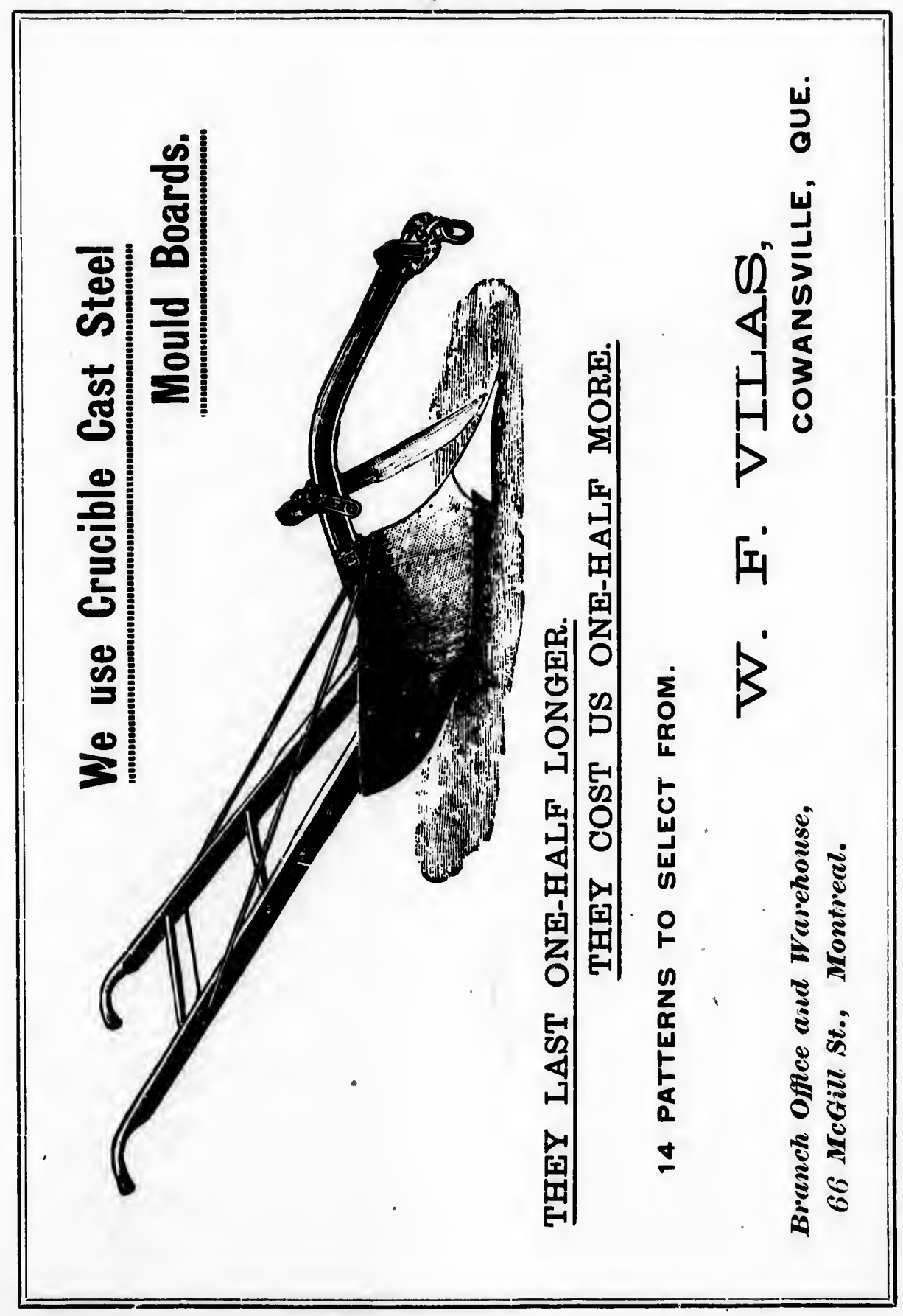


ENGLAND'S BLOCK.

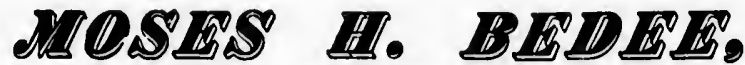 \\ YATOEMARER \& JPTHIFR, \\ Watch and Clock Repaiving a Specialty, \\ KNOWLTON.}

-

OUR STOCK OF WATCHES, CLOCKS,

JEWELRY, SILVERWANE, FANCY GOODS,

- SPECTACLES \& EYEGLASSES YOU WILL

FIND UP TO DATE IN EVERY RESPECT.

SOUVENIR GOODS ALWAYS ON HAND. .....

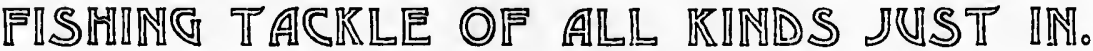

\section{LARGE LINE OF BOOKS \\ of the most Choice Selections, at any price you like to ask for.}

-

Largest Assortment in Town of Crockery, Glass and Chinaware, Fruit Jars, Stone Jars, \&c.

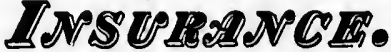

Missisuiuoi \& Rouville Mutual

Fire Insurance Gompany,

Western Gadledonian,

Ganada flccident.

\section{GET THE BEST \\ THE \\ Keating Bicycles,}

365 DAYS ABSAD

OF TESM ALL.

Ask to see the Roller Chain. 


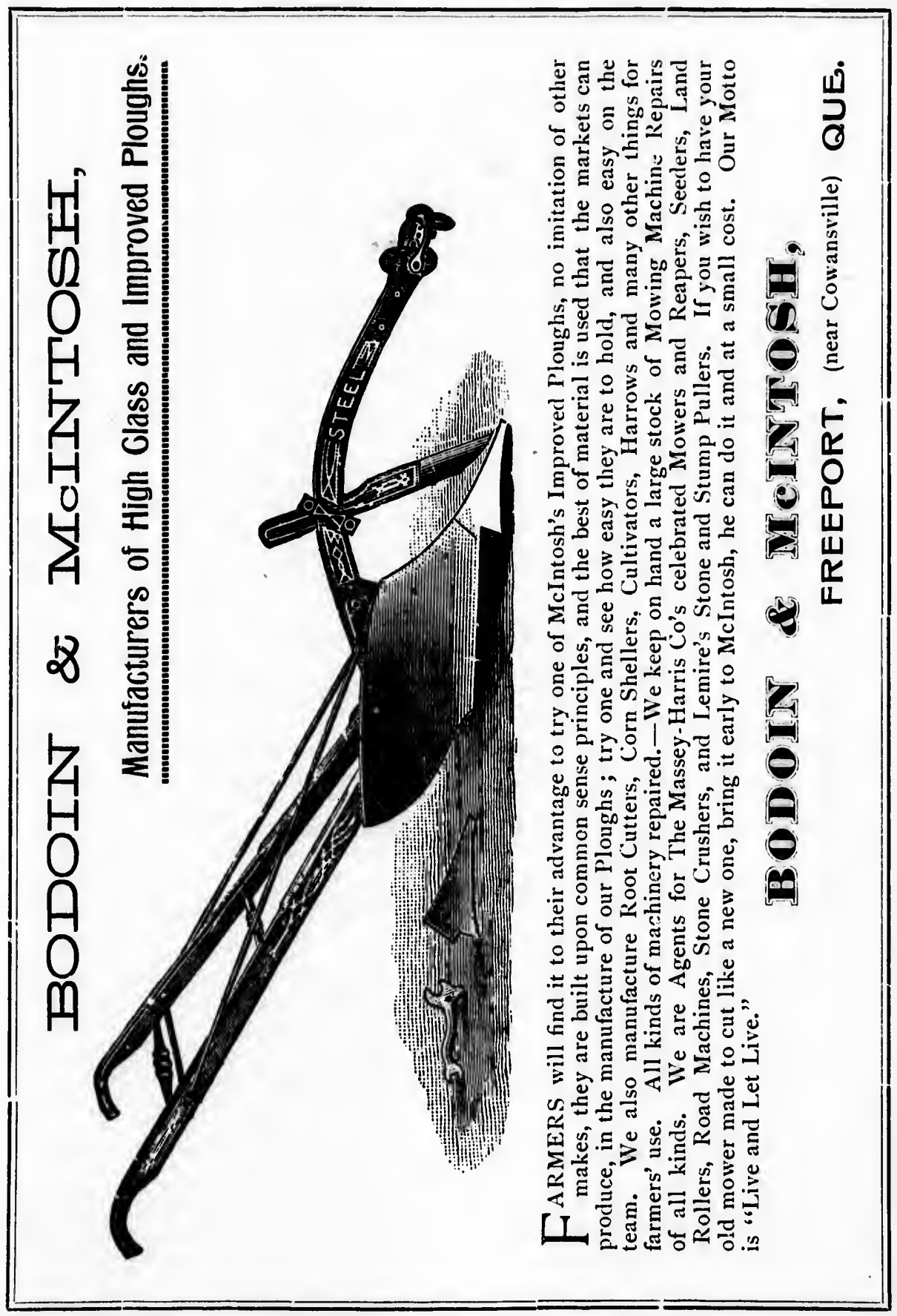




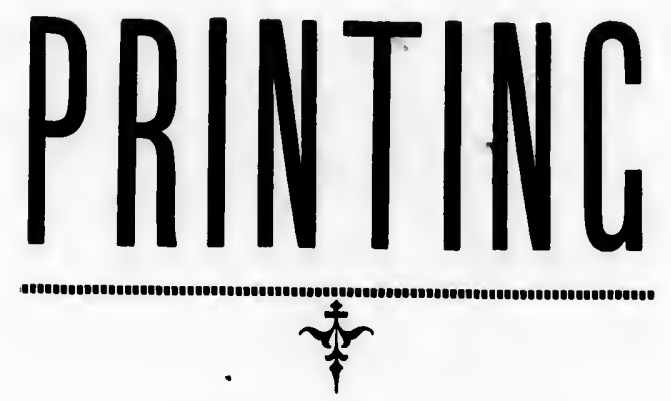

All kinds of Printed Stationery, Hand Bills, Auction Bills, Positers, Programmes,

- Cards, I'ickets, Labels, Invitations, \&c., in first-class style and at lowest prices.

A full line of Stationery and Blank Books at Montreal Prices.

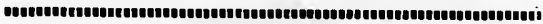

\section{H. F. SMITH, KNOWLTON, Q.}




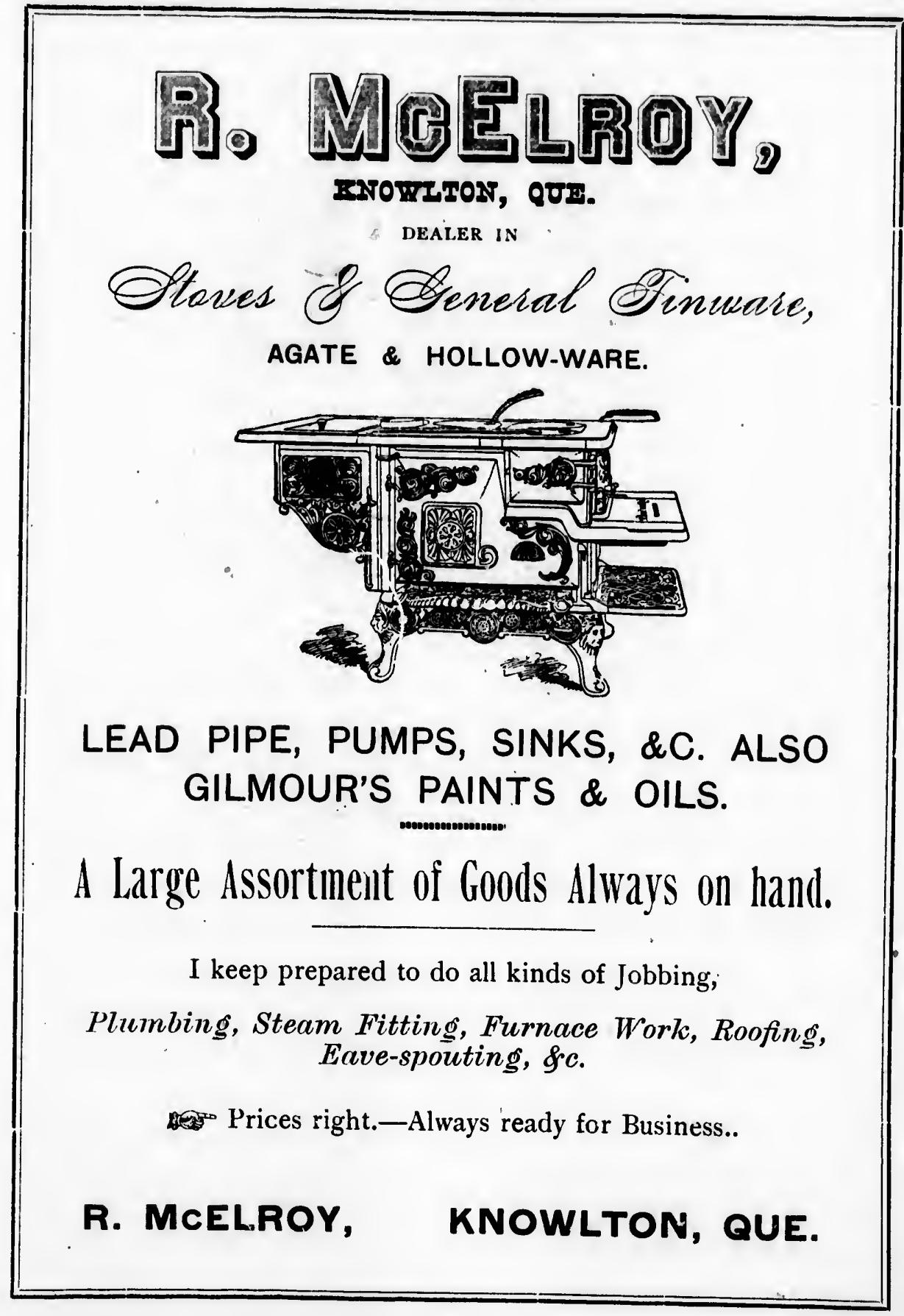


vi.

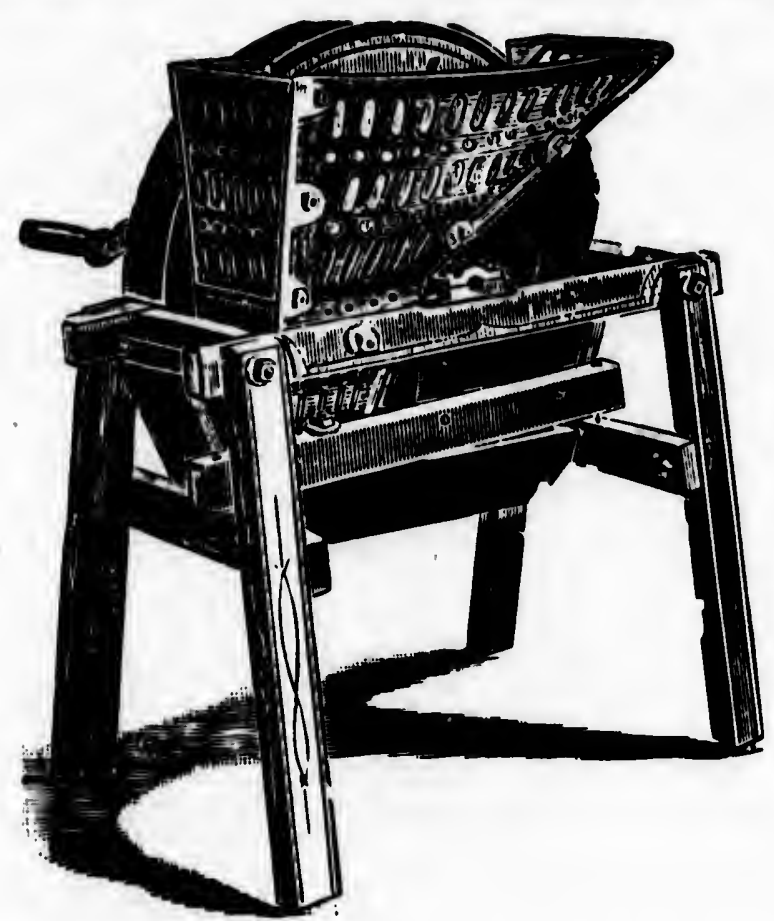

WE WILL NOT ENUMERATE THE MACHINES WE MAKE,

WE HAVE THEM ALL. You Know

Walter A. Wood Mowers are Good Mowers, Why experiment with others unless you wish to try the DEERING, they are 2nd to None. REPAIRS FOR ALL MACHINES. W. F. VIIAS, COWANSVILLE, QUE

Branch Office and Warehouse,

66 McGill St., Montreal. 
W. C. Trotter, Pres.

H. G. PERohaRd, Sec'r.

THE

STandard Drail PIpr Company, OF ST. JOHNS, P. Q. LIMITED.

- MANUPACTURERS OF -

SALT-GLAZED VITRIFIED DRAIN PIPES AND CONNECTIONS, DOUBLE STRENGTH CULVERT PIPES, INVERTS \& STOVE LININGS, GULLEY TRAPS AND ALL KINDS OF FIRE-CLAY GOODS.

"VI'TRIFIED PIPES MAKE THE BEST'

AND CHEAPEST FARM BRIDGES" AND ROAD CULVERTS.

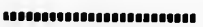

CATALOGUES AND PRICES ON APPLICATION. 
viii.

\section{EASTERN TOWNSHIPS FURNITURE EMPORIUM.}

By J. I. IEA.OFI, Cowransrillo.

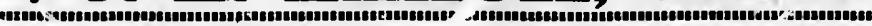

The place to buy your Furniture Direct from the Manufacturer and at one profit.

Gall and see.

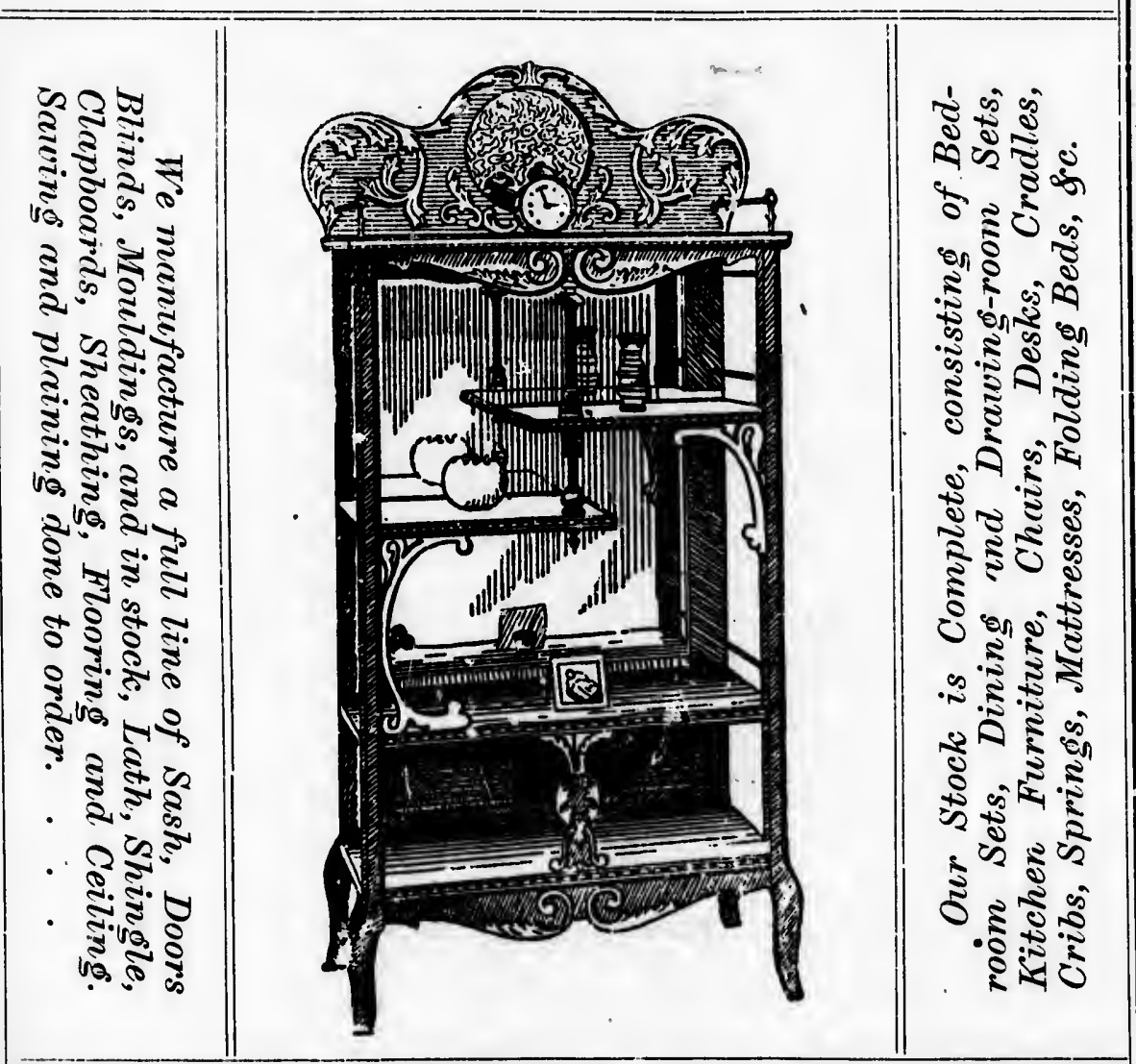

Remember we manufacture and sell direct and it will be to your interest to see us, as we have the Stock and Right Prices, at

$$
\text { J. I. IHAACFH'S, }
$$




\section{COUNTY OF BROME}

\section{Agricultural Saciety,}

\section{9.}

\section{BOARD OF DIRECTORS.}

\section{LYMAN KNOWL'TON, PRESIDENT.}

JOHN C. DRAPER, Gov Director.

O. J. Soles, - - Brome,
J. Cooey, -

W. H. Courser, - Sutton, T. W. Paige, - W. Bolton,
M. P. Eldnidge, - Potton, W. Curley, Vice-Pres. Sutton, R. D. Wells, - Farnham, Jas. Patterson, E. Bolton.

\section{HON. DIRECTORS.}

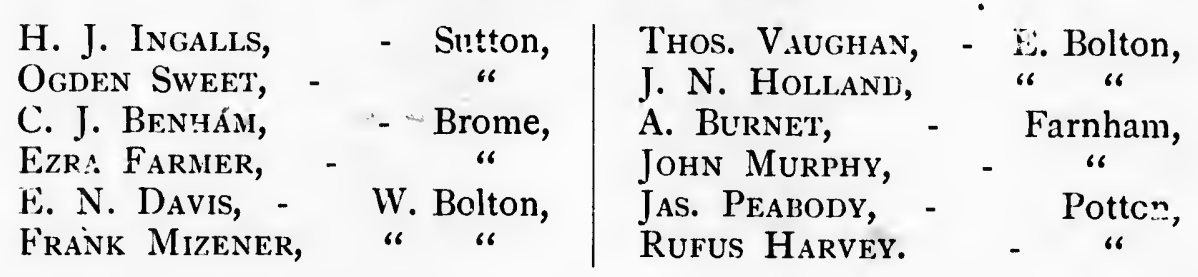

\section{SECRETARY - TREASURER.}

GEORGE F. HALL. 


\section{COMMITTEES OF DEPARTMENTS.}

\section{HORSES.}

Wm. Curley,

Directors in charge.

John CoOey.

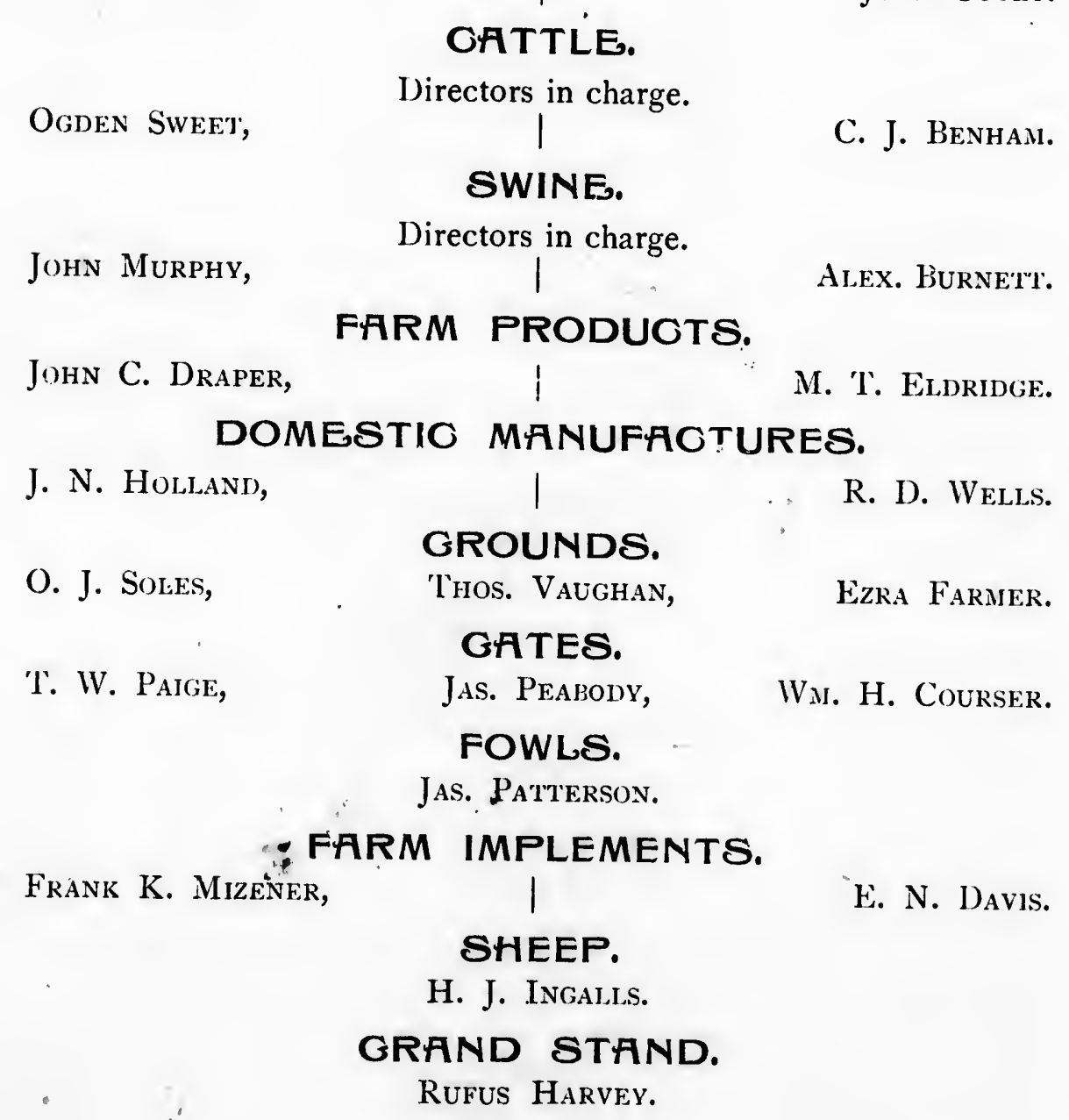

Ogben Sweet,

\section{GATTLE.}

Directors in charge. 


\section{Rules and Regulations.}

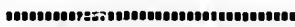

The Exhibition will be open to the public on Tuesday, September I 2 th, at 8 a. m., and will continue open until $6 \mathrm{p}$. m. on Wednesday.

First-class music will be provided during the two days Exhibition. A number of special attractions in addition to the regular Exhibition will be provided for the entertainment of visitors.

\section{ADMISSION TO THE GROUNDS.}

Members and their teams, Free.

Non-Members, 25c. Single teams, 25c. Double teams, $50 \mathrm{c}$.

Ladies, and children under ro years of age, Free.

Admission to Grand Stand, roc.

All members subscribing two dollars and upwards to the funds of the Society will be entitled to one stock attendant ticket provided he has stock on exhibition on the grounds.

All members subscribing one dollar or more will be entitled to two tickets, one for each day, such tickets well be taken up when presented at the gates and checks given to those members wanting to go out of the grounds and return.

1.- The Membership fee is one dollar, but no person shall be allowed to compete for any premiums on Farms unless he has paid an additional fee of one dollar and twenty-five cents into the funds of the Society. No person shall be allowed to compete on Kitchen Garden or Growing crops unless he has become a member and paid an additional fee of one dollar to the funds of the Society on or before the I 5 th July, and no person snall be allowed to compete for any other premium offered by the Society unless he shall have become a member and pay an entrance fee of fifty cents on each entry.

2.-Persons intending to compete at the Fall Show must make an entry of the same to the Secretary or one of the Directors at least four days previous to the Show. It is nevertheless provided that any person who may have subscribed and paid two dollars and upwards to the Secretary-Treasurer at the time specified in the first Rule, shall be entitled to compete for all animals, articles, etc., without paying an entry fee on the same. 
3.-All animals or articles entered for competition must be in their respective places on the Show Grounds by ten o'clock a. m. on the first day of the exhibition as above, and must not be removed from the same before two o'clock p.m., of the last day, unless by permission of a member of the Committee of Management.

4.-Brood Mares shall be accompanied by their foal of the present seasun.

5.-'That the competitor who enters his herd for competition at the time of the exhibition, must be the bona-fide owner, and a member of Society, at least two months next preceeding the day of exhibition. Brood animals excepted, which must have been kept for service in the county the past season, or upon the condition that they shall be kept for service upon reasonable terms, during the next season, in which latter case the prize will be paid after the season only.

6.--No animal or article shall be entered for more than one premium in the same year, except for special prizes.

7.-No competitor shall be entitled to more then one premium in the same class.

8.-Bulls must be secured so as to prevent the possibility of accident or injury; cows or other animals must be tied up on the show grounds; stallions must be confined to the limits prescribed by the Committee of Management, all under penalty of forfeiting the right of competition.

9.-Stallions and bulls may be exhibited by any member of the Society, provided that such animal has been kept in the county from the r,oth of May to July zoth, previous to the Show, for the use of the public by said member, on reasonable terms, at least two days in each week.

I0.-Domestic and other manufactured articles must have been made in this county since the $15^{\text {th }}$ September last, 1898 , by the competitor or some one in his employ.

I I.-All entries of thoroughbred stock for prizes must be accompanied with a deposite of a sufficiently authenticated certificate of its pedigree, to the satisfaction of the Secretary-Treasurer and Directors, and the same shall be kept on record by the Secretary-Treasurer.

I 2.-All farms, orchards and animals having received the First Premium shall not be allowed to compete in the same class for a period of of four years-brood animals excepted.

13.-Succe: sful competitors in Butter, Cheese and Maple Sugar shall furnish statements of the process of manufacturing the same; and successful competitors on Growing Crops shall furnish statements 
of the management and exfense of producing the same, etc., if required by the officers.

14.-All animals and articles entered for competition shall be ticketed and numbered and no person shall in any way interfere with the Judges in the execution of their duties. Any competitor so interfering shall forfeit the right of competition.

15.-Any member in the county whose farm lies partly in one township and partly in another will have the right to compete on the same, and the crops therein, in the township where he resides.

I6.-Any member exhibiting an article for premium, contrary to the rules of the Society, will forfeit all prizes awarded to him that year.

17.-Any and all questions of dispute that may arise shall be referred to the Officers and Directors for decision, who shall have the power to require the competitor to make oath he has conformed himself to the rules of the Society.

I 8.-Any member of the Society found guilty of loaning or in any wise giving the use of a badge to another person, shall forfeit all premiums obtained by him during the year.

19.-A member shall be the proprietor, proprietor's son living at home, or a tenant.

\section{Articles 84,85 \& 86 of the New Regulations now in Force.}

ART. 84.-Every Sheep exhibited at an exhibition must have been close shorn on or after the preceeding first of April.

ART. 85.-Competition for Thoroughbred Animals.-In Exhibition where prizes are offered for registered thcroughbred animals, no entry shall be accepted by the Secretary of the Society until he has received the regular official certificate proving the registration of the animal sought to be entered at such exhibition. No agricultural society shall have the right to offer lower prizes for thoroughbred than for grade animals.

ART. 86.-Examination of Stallions Entered for Prizes.-No stallion can be awarded a prize at Provincial, District or County Exhibitions unless he has previously obtained a certificate from a Veterinary Surgeon selected by the Society and approved by the Commissioner that such stallion is sound and in every way suitable for breeding. 


\section{RULES FOR JUDGES.}

1.-Judges shall be appointed by the officers and directors.

2.- They shall in all cases be sworn before acting as such.

3.- They shall in awarding premiums on bulls, cows and heifers, have reference to the quality of such animals for improvement of stock, and for dairy purposes; on oxen and steers to close matching, training, strength, etc.; on horses to those best adapted to all kinds of work; manufactured articles to the best manufactured of its kind on farms, reference to be had to the manner in which they are cultivated and managed, the improvements made the present year and the general appearance of the premises as indicative of the skill and industry of the proprietor, rather than the natural advantages or defects of the soil.

4.- No person will be allowed to act as Judge who is in any way interested in the stock to be examined.

5.-Should there be only one exhibit in a class or section the Judges can use their own discretion as to awarding a premium, and in all cases where they do not think the animal worthy, they can withhold the premium. Judges shall in no case award a prize unless they consider the exhibit actually worthy of such prize.

6.- Judges are expected, in the execution of their duties, to be careful to act with the most rigid impartiality.

7.-No animal or bird exhibited shall have about it any prize colors or cards, until the awards have been made in their respective classes.

8.-All prize cards which have been affixed by the Judges must be displayed during the Exhibition. Any infraction of this rule will ensure the forfeiture of any premium awarded.

9.-Any person not authorized to do so, conversing, or otherwise interfering with the Judges while on duty, will forfeit any right he may have for a prize, and it shall be the duty of the Judges to report to the secretary, on handing in the books, any infringement of this rule. 
Io.-Upon the discovery of any fraud, deception or dishonest practice, or misrepresentation in regard to any stock exhibit, which may have influenced, or may have been intended to influence the decision of the Judges, the Executive Committee have the power to withhold the payment of the prize awarded.

I I.-Any exhibitor lodging a protest must nake it in writing, and it must be delivered to the President or Secretary within three hours of the cause of protest.

12.- The Judges are particularly requested not to leave the grounds until they have ascertained from the Secretary that there are no protests against the awards in the classes they have judged.

13.-Any person or persons showing 'Thoroughbred Cattle as Grades will be disqualified.

14.- Judges will commence their work at to a. m. on Tuesday, the 12 th of September. Exhibitors will t'ierefore govern themselves accordingly.

An ample police force will be on duty day and night during the Exhibition. 'Telephone connection with the grounds.

Visitors are assured of finding on the grounds everything neccssary for their comfort and enjoyment.

\section{LYMAN KNOWLTON, President. WM. CURLEY, Vici-President. GEORGE F. HALL, Secretury.}

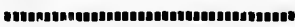

\section{NOTES.}

Every member of the Society will be liable to take the following oath if required by any other nember, viz:- "I do solemnly swear that all animals and articles exhibited by me are either my own growth, raising or manufacture, or acquired by me according to the rules of this Society. So help me God."

No entries will be receireá after Thursday, September 7th.

P. S.-Remember that the Annual Meeting for the election of Officers will be held at Brome Corner, on the THIRD WEDNESDAY IN DECEMBER. 


\section{PRIZE LIST FOR I899,}

\section{ON FARMS.}

'Townships Brome and Sutton.

Eight premiums .... \$7.00, 6.00, 5.00, 4.00, 3.00, 2.00, 1.00 .50 Do. All other Townships.

Six premiums $\ldots \ldots \ldots \ldots \ldots \ldots 5.00,4.00,3.50,2.50,2.00$, 1.00

\section{ON 1/2 ACRE CORN.}

Townships Brome and Sutton.

Six premiurns ........... 4.25, 3.25, 2.50, 2.00, 1.50, 1.00 Do. All other Townships.

Five premiums $\ldots \ldots \ldots \ldots \ldots \ldots \ldots 4.25,3.25,2.00,1.50$, 1.00

\section{ON $1 / 2$ ACRE FODDER CORN.}

Townships Brome and Sutton.

Seven premiums ....... 3.50, 3.25, 2.75, 2.00, 1.75, 1.50, 1.00 Do. All other Townships.

Six premiums $\ldots \ldots \ldots \ldots \ldots \ldots 3.50,3.25,2.75,2.00,1.50$, I.00

\section{ON I ACRE MIXED GRAIN.}

Peas \& Oats, Barley \& Wheat, or any two of them.

Townships Brome and Sutton.

Nine premiums $4.00,3.50,3.00,2.50,2.00,1.50,1.00, .50, .25$ Do. All other Townships.

Six premfiums $\ldots \ldots \ldots \ldots \ldots \ldots$ 4.00, 3.00, 2.00, 1.50, 1.00, .50 


\section{ON 1/2 ACRE POTATOES.}

Townships Brome and Sutten.

Six premiums ............. \$3.50, 3.00, 2.50, 2.00, 1.50, 1.00 Do. All other townships.

Five premiums $\ldots \ldots \ldots \ldots \ldots \ldots \ldots$ 3.00, 2.50, 2.00, 1.50, 1.00

\section{ON 1/2 ACRE RUTABAGAS.}

Townships Brome and Sutton

Six premiums .............. 3.00, 2.50, 2.00, 1.50, 1.00, .50 Do. All other Townships, $1 / 8$ Acre.

Four premiums ................ 2.50, 2.00, 1.50, 1.00

\section{ON I ACRE OATS.}

Townships Brome and Sutton.

Eight premiums ..... 3.50, 3.00, 2.50, 2.00, 1.50, 1.00, ..50, .25 Do. All other Townships.

Six premiums ............ 3.00, 2.50, 2.00, 1.50, 1.00, .50

\section{ON KITCHEN GARDEN.}

Special Gardens, Township of Sutton, 2 premiums .... \$2.00, 1.00 Special Gardens, Township of Brome, competitors to be named,

2 premiums ....................... 2.00, i.oo Farmers' Gardens, 3 premiums . ........... 2.50, 2.00, 1.00 All other Townships, 3 premiums........... 3.00, 2.00, 1.00 Note. - No crop shown as a crop shall be included in a garden.

\section{ON FARM CROPS.}

On acre Wheat, 4 premiums..........\$2.50, 2.00, 1.50, 1.00 On Orchards, 4 premiums ............ 3.00, 2.50, 2.00, 1.00 On best acre Barley, 4 premiums......... 3.00, 2.00, 1.00, .50 On best half acre Peas, 3 premiums........... 2.00, 1.50, 1.00 On best eighth acre Beans, 3 premiums........ 2.00, 1.50, 1.00 On eighth acre Carrots, 4 premiums ...... 2.50, 1.50, .75, .50 On eighth acre Mangold Wurtzel or Sugar Beets

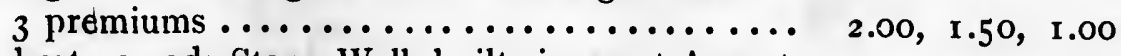

On best ro rods Stone Wall, built since ist August altogether in one place, 3 premiums ....... 3.00, 2.00, 1.00

On best 20 rods Çovered Ditch, made since ist August

last past, 3 premiums ............... 3.00, 2.00, 1.00

On best 20 rods Open Ditch, made since rst August last past, 3 premiums ............... 3.00, 2.00, 1.00 


\section{HORSES.}

On making entries the owner's name and address in full, the name of the animal (if named), and age, should be given. No horse will be allowed to comrete in more than one class or section except for special prize.

All horses entered as registered, pedigrees and numbers must accompany entries and be shown with horses when before the Judges. In no case will any standard or registered horse be allowed to compete in any other class except for specials. Any person or persons showing standard-bred horses in any other classes than that in which they belong shall be disqualified.

No Stallion can be awarded a prize unless he has previously obtained a certificate from a Veterinary Surgeon, approved by the Council of Agriculture, that such Stallion is sound and in every way suitable for breeding. A duly qualified Veterinary Surgeon will be on the grounds for that purpose and will be paid by the Association.

The upper door of stalls must be left open from 9 a.m. to 6 p.m., in order that the public may view the animals.

STALLIONS.

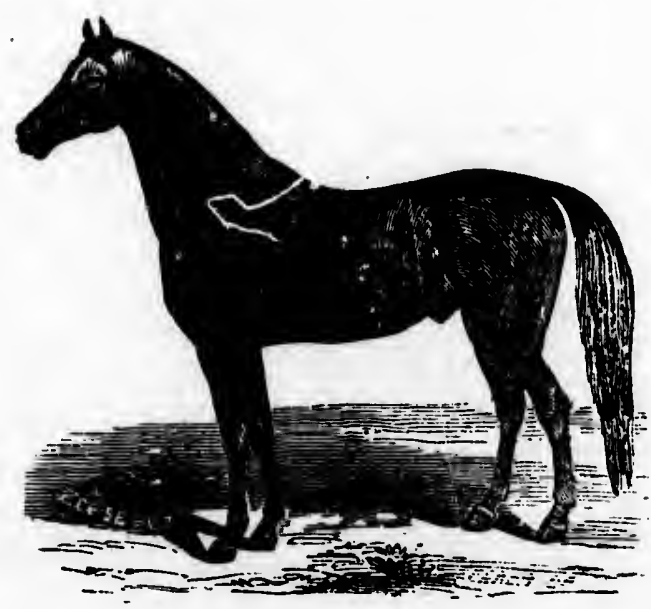


On Carriage Stallions, registered, any breed, 3 premiums... $\$ 4,3,2$ On Draught " " " 3 premiums... 4, 3,2 On Stallion Colts, 3 years old, registered, any breed. exhibited in harness, 3 premiums.............. 3, 2, I On Stallions 2 years old, registered, any breed, 3 premiuns 3,2 , I On registered Brood Mares, with foal, any breed, 2 prem. .. $\quad 3,2$

ROADSTERS, 心C.

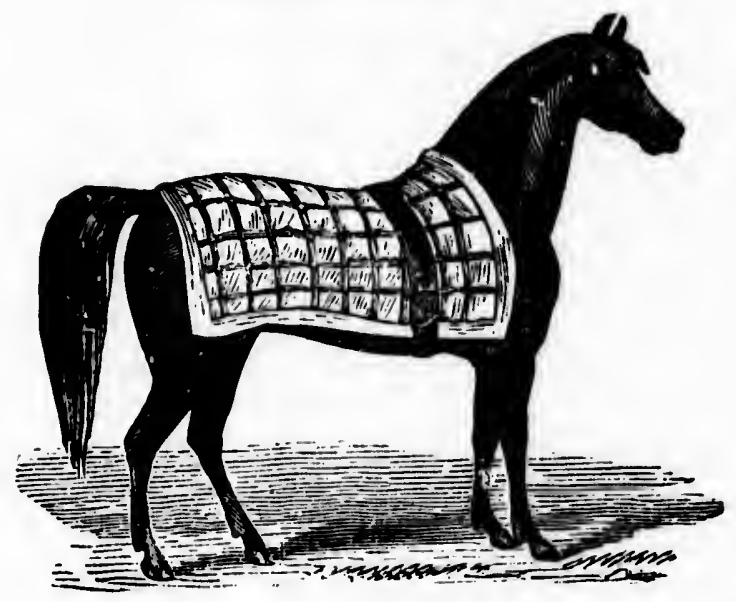

On yearling Carriage Colts, stallions, mares or geldings, 4 premiums .................. \$2,00, I.50, I.00, .50 On Brood Mares, accompanied by their foal of the present year, I5.I hands and over, 3 premiums...... 2.00, I.50, 1.00 On Brood Mares, accompanied by their foal of the present year, under I 5.1 hands, 3 premiums........... 2.00, 1.50, 1.00 On Carriage Mares or Geldings, 3 y'rs old, shown single in hạness, 4 premiums ............ 3.00, 2.50, 2.00, 1.00 On Carriage Mares or. Geldings, 2 y'rs old, 3 prem. 3.00, 2.00, I.00 On pair matched 3 year old Colts, mares, geldings, or both, in harness, 3 premiums............... 3.00, 2.00, 1.00 On Single Carriage Horse, gelding or mare, under ro y'rs old, under I 5.1 hands, 7 prem. ... 5.00, 4.00, 3.00, 2.50, 2.00, I.50, I.00 On same, over I5.1 hands

7 premiums ......... 5.00, 4.00, 3.00, 2.50, $2.00,1.50,1.00$ On pair Matched Horses, geldings, mares, or both, under

Io y'rs old, I 5.I' hands and over, 3 prem. .... 4.00, 3.00, 2.00 On same, under I 5.1 hands, 3 premiums....... 4.00, 3.00, 2.00 


\section{DRAUGHT HORSES.}

On yearling Draft Colts, Stallions, Mares or Geldings, 2 prem. \$2. I On Draught Mares or Geldings, 3 years old, shown single in harness, 2 premiums................... 3 , 2 On Draught Mares or Geldings, 2 y'rs old, 2 premiurns..... 3, 2 On pair Draught Horses to farm wagon, 3 prem. ... 2.50, I, .50

\section{REGISTERED CATTLE.}

In making entries, give the owner's name and address in full, the age of the animal, and its name (if named).

Certificate of registration must be shown to the Directors in charge at time of exhibiting, stock, and no competitor will be awarded a prize without a certificate.

Bulls must have rings in their noses or be otherwise properly secured to prevent accident.

All animals will be shown in the arena or ring. Owners or attendants must be prepared to bring them out when called for or forfeit claims to any premiums awarded.

Any person or persons, showing thoroughbred registered cattle as Grades, will be disqualified.

Not more than one prize in any one section will be given to any one exhibitor.

\section{DURHAMS.}

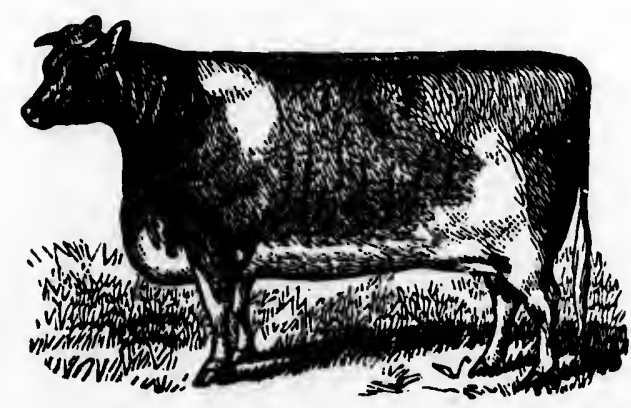


On Bull, 2 years old and upwards, 2 premiums ......... $\$ 4,2$ On Bull, I year old, 2 premiums ............... 4, 2 On Bull Calf, under 1 year, 2 premiums ............ 2 , On Cow, 3 years old and upwards, in milk, 2 premiums.... 4, 2 On Heifer, 2 years old, in milk, 2 premiums ........... 2 , I On Heifer, 2 years old, 2 premiums $\ldots \ldots \ldots \ldots \ldots \ldots \ldots . . \ldots \ldots \ldots$

On Heifer, I year old, 2 premiums............... On Heifer Calf, under I year, 2 premiums...........

HOLSTEINS.

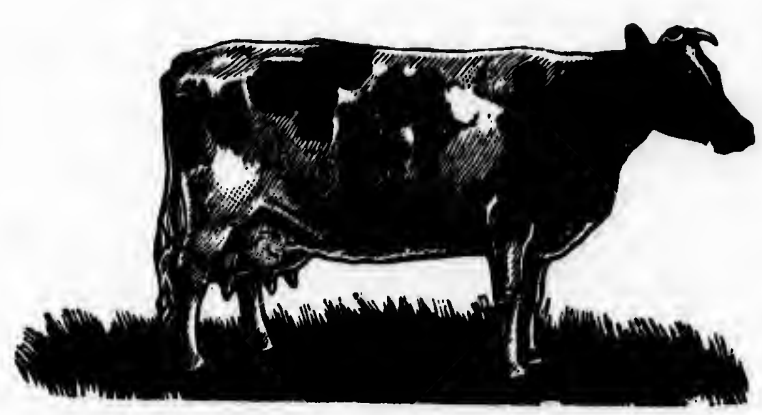

On Bull, 2 years old and upwards, 2 premiums $\ldots \ldots \ldots \ldots \$_{4}, 2$ On Bull, I year old, 2 premiums............... 4,2 On Bull Calf, under one year, 2 premiums $\ldots \ldots \ldots \ldots \ldots . . \ldots \ldots$, I On Cow, 3 years old and upwards, in milk, 2 premiums.... 4,2 On Heifer, 2 years old, in milk, 2 premiums $\ldots \ldots \ldots \ldots \ldots .2$, I On Heifer, 2 years old, 2 premiums $\ldots \ldots \ldots \ldots \ldots \ldots \ldots$, On Heifer, I year old, 2 premiums............. I On Heifer Calf, under I year, 2 premiums.......... 


\section{GUERNSEYS.}

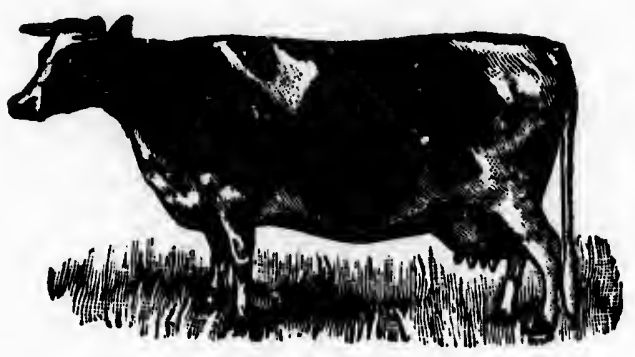

On Bull, 2 years old and upwards, 2 premiums $\ldots \ldots \ldots \ldots \$ \$ 4,2$

On Bull, I year old and upwards, 2 premiums $\ldots \ldots \ldots \ldots . \ldots 4,2$ On Bull Calf, 2 premiums $\ldots \ldots \ldots \ldots \ldots \ldots \ldots \ldots \ldots$, On Cow, 3 years old and upwards, in milk, 2 premiums .... 4, 2 On Heifer, 2 years old, in milk, 2 premiums $\ldots \ldots \ldots \ldots \ldots$ 2, I On Heifer, 2 years old, 2 premium.............. 2 , I On Heifer, r year old, 2 premiums............. 2 , I On Heifer Calf; 2 premiums $\ldots \ldots \ldots \ldots \ldots \ldots \ldots \ldots \ldots$, I

FERSEYS.

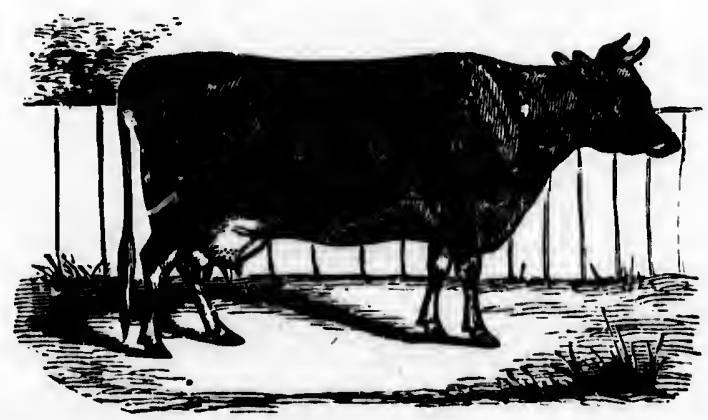


On Bull, 2 years old and upwards, 2 premiums $\ldots \ldots \ldots \ldots \$ \$_{4}, 2$

On Bull, I year old, 2 premiums $\ldots \ldots \ldots \ldots \ldots \ldots \ldots \ldots$ 4, 2

On Bull Calf, under I year, 2 premiums $\ldots \ldots \ldots \ldots \ldots \ldots$, I

On Cow, 3 years old and upwards, in milk, 2 premiums.... 4,2

On Heifer, 2 years old, in milk, 2 premiums $\ldots \ldots \ldots \ldots \ldots$ 2, I

On Heifer, 2 years old, 2 premiums $\ldots \ldots \ldots \ldots \ldots \ldots \ldots$, , I

On Heifer, I year old, 2 premiums $\ldots \ldots \ldots \ldots \ldots \ldots \ldots \ldots$, ,

On Heifer Calf, under 1 year, 2 premiums..........

AYRSHIRES.

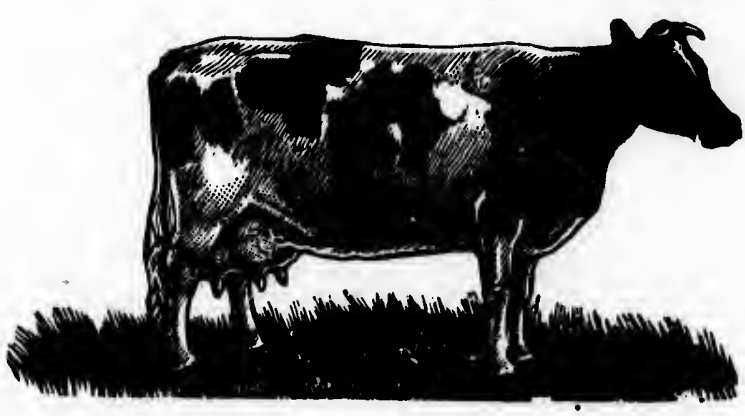

On Bull, 2 years old and upwards, 2 premiums ........ \$ 4,2 On Bull, x year old, 2 premiums.............. 4, 2 On Bull Calf, under one year, 2 premiums .......... 2 , I

On Cow, 3 years old and upwards, in milk, 2 premiums.... 4, 2 On Heifer, 2 years old, in milk, 2 premiums .......... 2 , I On Heifer, 2 years old, 2 premiums $\ldots \ldots \ldots \ldots \ldots \ldots \ldots$, , I On Heifer, I year old, 2 premiums............. I On Heifer Calf, under I year, 2 premiums.......... 2 , I 


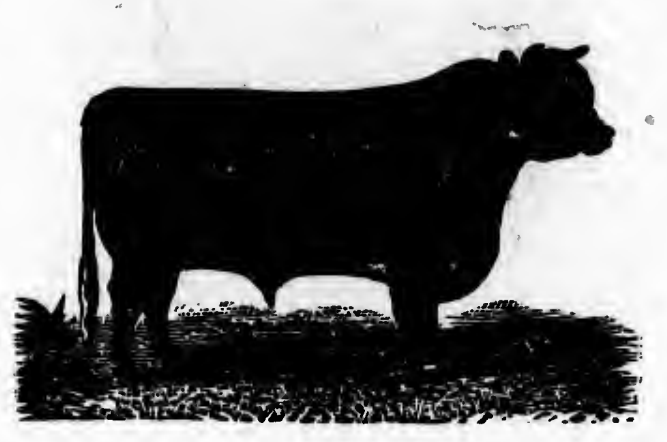

\section{REGISTERED CANADIAN CATTLE, OR CANADIAN JERSEY CATTLE.}

All animals exhibited in this Class must be Registered.

On Bull, 2 years old and upwards, 2 premiums $\ldots \ldots \ldots \ldots . \$ 4,2$

On Bull, I year old and upwards, 2 premiums $\ldots \ldots \ldots \ldots . \ldots 4,2$ On Bull Calf, 2 premiums $\ldots \ldots \ldots \ldots \ldots \ldots \ldots \ldots \ldots$, On Cow, 3 years old and upwards, in milk, 2 premiums .... 4, 2 On Heifer, 2 years old, in milk, 2 premiums $\ldots \ldots \ldots \ldots \ldots$, On Heifer, 2 years old, 2 premium.............. 2 , I On Heifer, r year old, 2 premiums............. , I On Heifer Calf, 2 premiums $\ldots \ldots \ldots \ldots \ldots \ldots \ldots \ldots \ldots \ldots \ldots$, 


\section{GRADE CATTLE.}

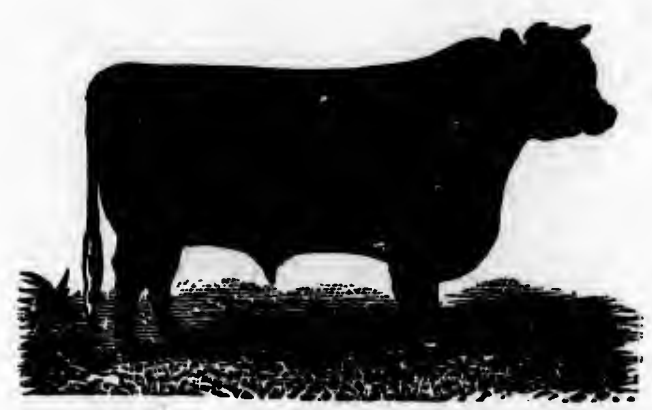

On Cows in milk, 7 prem. .. \$4.00, 3.50, 3.00, 2.50, 2.00, 1.50, I.00 On Heifers 3 years old, in milk, 5 prem. 3.50, 3.0o, 2.50, 2.00, 1.00 On Heifers 2 years old, in milk, 4 prem. .....2.50, 2.00, 1.50, 1.00 On Heifers 2 y'rs old, not in milk, 4 prem... 2.00, I.50, 1.00, .50 On Heifers I year old, 3 premiums .......... 2.00, 1.50, 1.00 On Heifer Calves, age to be considered,

4 premiums $\ldots \ldots \ldots \ldots \ldots \ldots \ldots \ldots \ldots .2 .50,2.00,1.50$, I.00

\section{( WORKING OXEN.)}

On pair of Oxen 4 years old and up, trained to work,

3 premiums................... \$6.00, 4.00, 2.00 On pair 3 year old Steers, trained for work, 3 premiums.................... 5.00, 4.00, 2.00 On pair 2 year old Steers, trained for work,

3 premiums............................ 4.00, 2.00, 1.00

On pair yearling Steers, trained for work,

3 premiums........................ 1.50 , 1.00

On pair Steer Calves, trained for work,

3 premiums.......................... 2.0 I.50, 1.00

monnm

Look for long List of Special Prizes on Classified Grade Cattle. 


\section{SWINE.}



REGISTERED SWINE.

Berkshire, Essex, Suffolk and other Swall Breeds.

Certified Pedigree to accompany animal at Exhibition.

On Boars over I year old, 3 premiums $\ldots \ldots \ldots \ldots \$ 3.00,2.00$, I.00 On Boars over 6 mos. and under I year, 3 prem .. 3.00, 2.00, I.00 On Boars over 2 mos. and under 6 mos. 2 premiums.... 2.00, I.oo On Sow Pig under 6 mos., 2 premiums............ 2.00, 1.00 On Sow Pig over 6 mos, and under I y'r, 3 prem. - 3.0o, 2.00, I.00 On Sow with Litter, 4 prem. (see note below) 4.00, 3.00, 2.00, I.00 On Sow of any age, 2 premiums $\ldots \ldots \ldots \ldots \ldots \ldots \ldots 3 . \ldots \ldots, 2.00$

\section{REGISTERED SWINE.}

Chester White, and other Large Breeds.

Certified Pedigree to accompany animal at Exhibition.

On Boars over I year old, 4 premiums ..... \$4.0p, 3.00, 2.00, I.00 On Boars over 6 mos. and under one year, 3 prem. 3.00, 2.00, 1.00 On Boars over 2 mos. and under 6 mos., 2 premiums ... 2.00 , 1.00 On Sow Pig under 6 mos., 2 premiums............ 2.00, 1.00 On Sow Pig over 6 mos. and under I year, 3 prem 3.0o, 2.00, 1.00 On Sow with Litter, 4 prem.(see note below) 4.00, 3.00, 2.00, 1.00 On Sow of any age, 2 premiums $\ldots \ldots \ldots \ldots \ldots \ldots \ldots$ 3.00, 2.00

SWINE. Grades and Crosses.

On Sow Pig under 6 mos. 2 premiums $\ldots \ldots \ldots \ldots \ldots \ldots \$ 2.00$, 1.00 On Sow Pig over 6 mos. and under I year, 2 prem. .... 2.00 , 1.00 . On Sow with Litter, 4 prem. (see note below) 4.00, 3.00, 2.00 , I.00 On Sow of any age (large breed), 2 premiuns....... $3.00,2.00$ On Sow of any age (small breed), 2 premiums....... 3.00, 2.00

No're.-Litter of not less than 4 pigs, and pigs not over 2 months old. 


\section{SHEEP.}

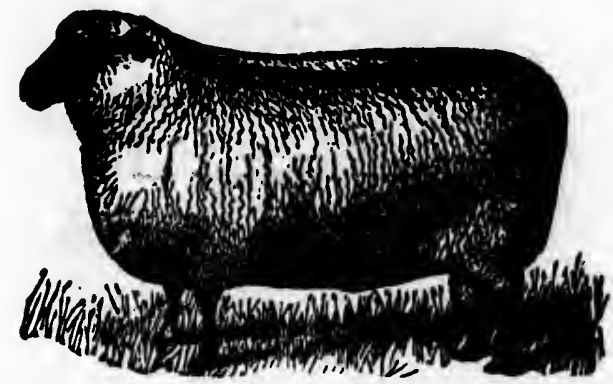

REGISTERED SHEEP. Long Wool.

Certified Pedigree to accompany animal at Exhibition.

On Rams 2 years old and upwards, 4 prem...\$2.00, 1.50, 1.00, .50 On Rams I year old, 4 premiums ........ 2.00, r.50, r.00, .50 On Ram Lambs, 4 premiums ........... 2.00, 1.50, 1.00, .50 On two Ewes, 4 premiums ............. 2.00, 1.50, 1.00, .50 On two Yearling Ewes, 4 premiums........ 2.00, 1.50, 1.00, .50 On two Ewe Lambs, 4 premiums......... 2.00, 1.50, 1.00, .50

\section{REGISTERED SHEEP. Fine Wool.}

Certified Pedigree to accompany animal at Exhibition.

On Rams 2 years old and upwards, 4 prem... \$2.00, 1.50, 1.00, .50 On Rams t year old, 4 premiums ......... 2.00, 1.50, 1.00, .50 On Ram Lambs, 4 premiums ............ 2.00, 1.50, 1.00, .50 On two Ewes, 4 premiums ............ 2.00, 1.50, 1.00, .50 On two Yearling Ewes, 4 premiums........ 2.00, 1.50, 1.00, .50 On two Ewe Lambs, 4 premiums......... 2.00, I.50, I.00, .50

\section{SHEEP; GRADES \& CROSSES, Long Wool.}

On two Ewes, 4 premiums ............\$2.00, 1.50, 1.00, .50 On two Yearling Ewes, 4 premiums ....... 2.00, 1.50, 1.00, .50 On two Ewe Lambs, 4 premiums......... 2.00, 1.50, 1.00, .50

\section{SHEEP, GRADES \& CROSSES, Fine Wool.}

On two Ewes, 4 premiums $\ldots \ldots \ldots \ldots \ldots \ldots \$ 2.00$, 1.50, 1.00, .50 On two Yearling Ewes, 4 premiums........ 2.00, 1.50, 1.00, .50. On two Ewe Lambs, 4 premiums......... 2.00, 1.50, 1.00, .50 


\section{POULTRY.}

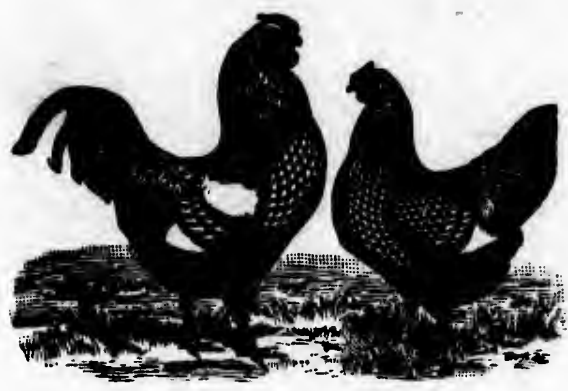

FOWLS. (HENS.)

Wyandotts, 2 premiums ................ 50 cts. 25 cts.

Best pair Wyandott Chickens, 2 premiums....... 50 " 25 "

Light Brahmas, 2 premiums............... 50 " 25 "

Best pair Brahma Chickens, 2 premiums........ 50 " 25 "

Plymouth Rocks, 2 premiums .............. 50 " 25 "

Best pair Plymouth Rock ('hickens, 2 premiums .... 50 " 25 "

White Leghorns, 2 premiums.............. 50 " 25 "

Best pair Brown or White Leghorn Chickens, 2 prem. 50 " 25 "

Silver Spangled Hamburgs, 2 premiums .........

Best P'r Silver Spangled Hamburg Chick's, 2 prem. . 50 “ 25 “

Best Collection of Hens and Chickens .............. \$2.00

\section{.GEESE.}

On best pair White Chinas, 2 premiums........ 50 cts. $25 \mathrm{cts}$.

On best pair, any other variety, 2 premiums $\ldots . . .5$ 50 " 25 "

On best pair Bronze Turkeys, 2 premiums ....... 50 " 50 " 25 "

On best pair White Holland 'Turkeys, 2 premiums .. 50 " 25 “

On best pair Black Turkeys, 2 preminims ......... 50 " 25 “

On best pair Pekin Ducks, 2 premiums......... 50 “ 25 “

On best pair Aylesbury Ducks, 2 premiums ....... 50 " 25 "

On best pair Peacocks, 2 premiums .......... 50 " 40.

On Best Collection Ducks, Geese and Turkeys........... \$2.00 


\section{DAIRY PRODUCTS, ETC.}

Market packed Dairy Butter, 25 lbs. or more in each package, 3 premiums ..................\$2.50, I.50, I.00 Best package of Creamery Butter, not less than $30 \mathrm{lb}$. package,

3 premiums .................... 3.00, 2.00, 1.00 Market packed Dairy Separator Butter, 3 prem. .. 2.50, r.50, I.00 Dairy Separator Butter cannot be exhibited as Creamery Butter.

Factory Cheese, to be exhibited by the manufacturer or committee, not less than 50 lbs. nor less than 2 cheese,

3 premiums ..................... 3.00, 2.00, 1.00 On best sample Maple Syrup, to be exhibited in I quart

gem jars, 3 premiums............... 1.00, .75, .50 On Maple Sugar, in cakes, ro lbs., 3 premiums ... 1.oo, $\quad .75, \quad .50$ Honey, in comb, ro lbs., 2 premiums......... 1.00, .50 Honey, extracted, not less than ro lbs. 2 prem. .. $\quad$ r.oo, .50

Nore. - Not more than one prize, special or other, to be awarded on any one package of Butter.

\section{LADIES' DEPARTMENT.}

\section{DOMESTIC MANUFACTURES.}

Patchwork Bed Quilt, Silk, 3 premiums ......\$ \$1.50, r.oo, .50 Best Rag Carpet, not less than ro yds, 3 prem.... 2.00, 1.50, r.oo Pair Ladies' Wool Stockings, 2 premiums............ $.50, \quad .25$ Pair Fancy Mittens, 2 premiums.................. .50, $\quad .25$ Carriage Lap Robe, 3 premiums $\ldots \ldots \ldots \ldots \ldots \ldots \ldots \ldots$ I.50, $1.50, \quad .50$ Rug of any king, braided, 2 premiums ........... 1 .oo, .50 Collection Ladies' Fancy Needlework, 4 prem 3.00, 2.00, 1.00, .50 Collection Plain Needlework, 2 premiums .......... 2.00, 1.00 Patchwork Bed Quilt, Worsted, 3 premiums...... I.50, 1.00, .50 Patchwork Bed Quilt, Print, 3 premiums ........ 1.50, 1.00, .50 Bed Coverlet, Crochet or knitted, 3 premiums.... 1.50 , 1.00, .50 Fancy Sofa Pillow, 3 premiums $\ldots \ldots \ldots \ldots \ldots \ldots$ r.00, $.50, \quad .25$ Rug of any kind, drawn, 2 premiums $\ldots \ldots \ldots \ldots \ldots \ldots \ldots$ 1.00, .50 Crochet Work, 2 premiums .................. 1.00, .50 Drawn Work, 2 premiums .................. $\quad .75, \quad .50$ Hand Knit Case, 2 premiums $\ldots \ldots \ldots \ldots \ldots \ldots \ldots \ldots \ldots . .75, \quad .50$ Painting on Satin, 2 premiums.............. .50, .25 Painting on Plush or Velvet, 2 premiums.......... $.50, \quad .25$ 


\title{
MECHANICAL WORK.
}

Best Phæton or other Covered Carriage $\ldots \ldots \ldots \ldots \ldots \ldots \ldots \$ \mathbf{\$ 2 . 0 0}$

Best Buggy, Open........................ 2.00

Best Double Wagon with Box $\ldots \ldots \ldots \ldots \ldots \ldots \ldots \ldots \ldots, 2.00$

Best Express Wagon with Box................. 2.00

'Two-Seated Sleigh......................... 2.00

Best Pleasure Sleigh $\ldots \ldots \ldots \ldots \ldots \ldots \ldots \ldots \ldots \ldots \ldots \ldots, 2.00$

Pair Farm Bob-sleds........................ 2.00

Best Single Harness $\ldots \ldots \ldots \ldots \ldots \ldots \ldots \ldots \ldots \ldots \ldots$ r.oo

Best Pair Work Harnesses . ................... 2.00

Best Pair Light Harnesses .................... I.00

Best Chamber Set ....................... 2.00

Best Collection Agricultural Implements, 2 prem. .... \$5.0o, 3.00

Machinery in Motion ..................... 5.00

\section{MANUFACTURER'S DEPARTMENT.}

\author{
Open to the District of Bedford and Stanstead County.
}

Best Collection of Manufactured Woolen Goods,

2 premiums ........................\$5.00, 3.00

\section{DISCRETIONARY PRIZES.}

The sum of $\$ 25$ is offered for Discretionary Prizes for useful manufactured articles of mechanical work manufactured in the County, exhibited and not enumerated in the above list, besides the prizes above offered, providing the Judges thereon shall ?eem the specimens exhibited sufficiently numerous and worthy.

Look for long List of Special Prizes to be issued August ist. 


\section{8. C: LIST OF PREMIUMS OBTAINED. ?}

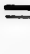

b
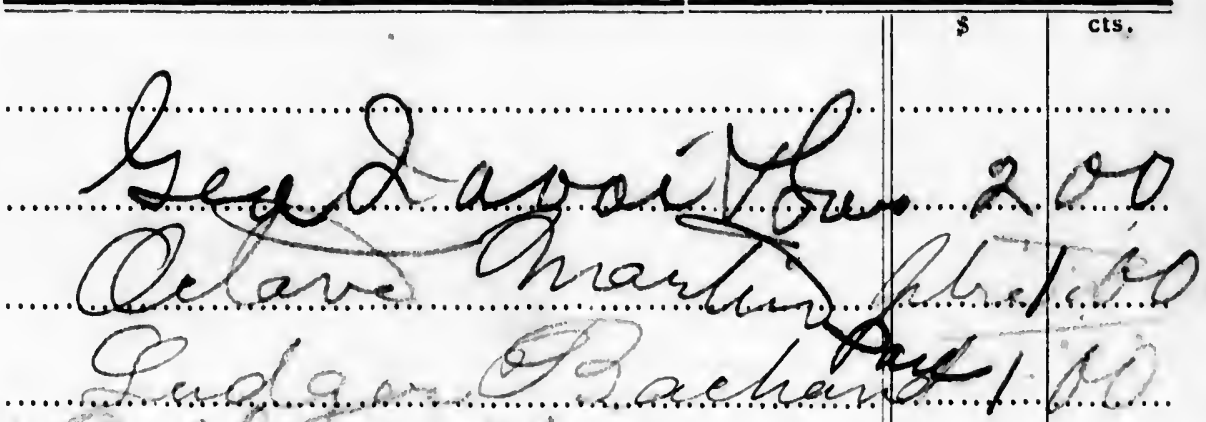

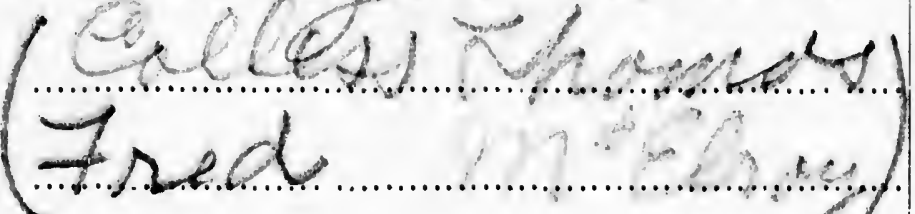

thenct $x$ $100 \mathrm{y}$

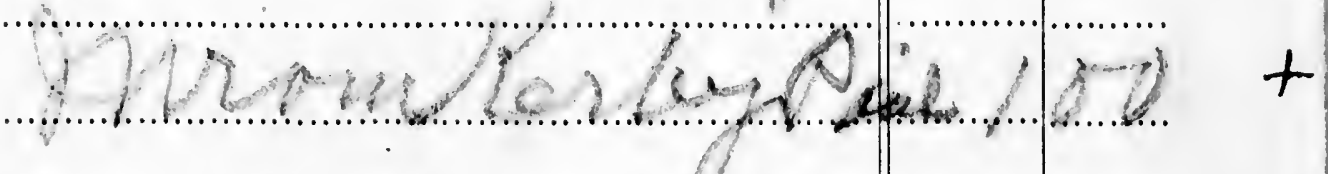
8mu oceells

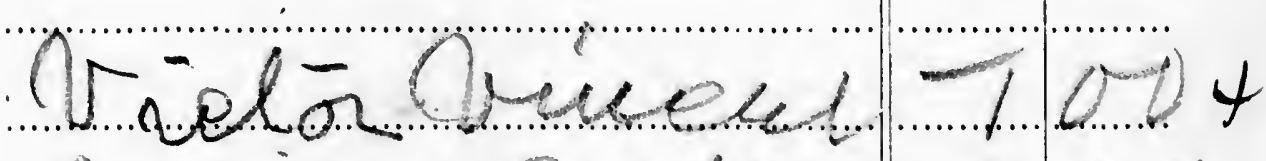

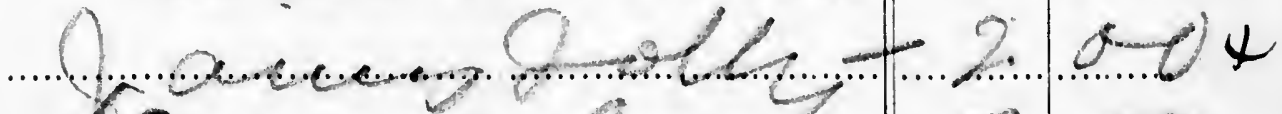

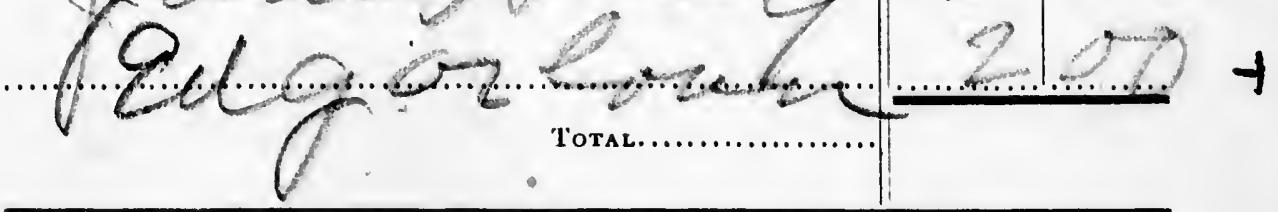

COMPETITOR'S PREMIUM GHEGK PAGE. 

The full pleasures of Bicycling is only to be had by the use of the Best Wheel.

\section{THE COLUMBIA BICYCLES, "standard of the world."}

Will please you both as to Quality and Price.

\section{THE HARTFORD BICYCLES,}

Second only to "Columbias" and equal,

if not superior, to any of the high grade wheels on the market, at fully one-third less cost. - The Hartford is the greatert bicycle value ever offered.

Just look at these Bicycles before buying.

For SAle bY

\section{H. F. SMITH, - KNOWLTON.}




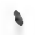

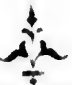

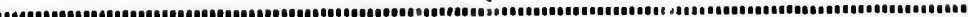
- B̧ROME COUNTYY

\section{Horticultural Assiciation} - WII. H(1)1, ITS -

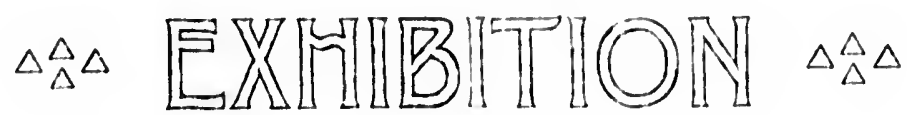

\section{Brome Corner. P. Q.}

12 th \& 1:3th SEPTEMER, 189!).

II. C. KNOWITON, PRishrint.

II. M. IIILIIIOL'-E, SIERITARY.

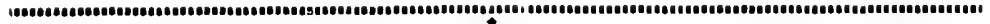
齐 


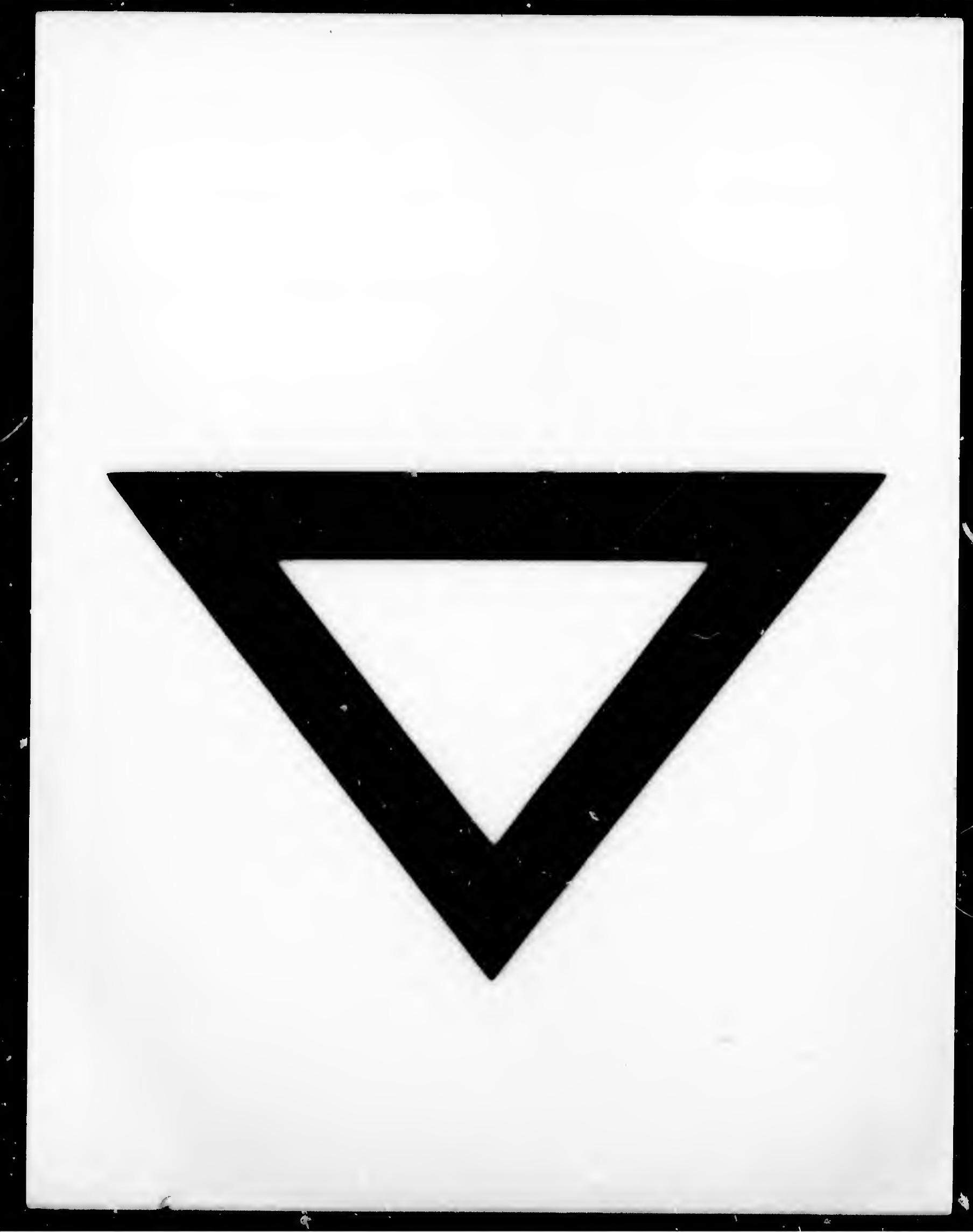

